\title{
Article \\ Mineral Biofortification and Growth Stimulation of Lentil Plants Inoculated with Trichoderma Strains and Metabolites
}

\author{
Roberta Marra ${ }^{1,2, *(\mathbb{D})}$, Nadia Lombardi ${ }^{1,2} \mathbb{D}$, Alessandro Piccolo ${ }^{1,3}$, Navid Bazghaleh ${ }^{4}$, Pratibha Prashar 4 , \\ Albert Vandenberg ${ }^{4}\left(\mathbb{D}\right.$ and Sheridan Woo ${ }^{2,5,6}$ (i)
}

check for

updates

Citation: Marra, R.; Lombardi, N.;

Piccolo, A.; Bazghaleh, N.; Prashar, P.; Vandenberg, A.; Woo, S. Mineral Biofortification and Growth Stimulation of Lentil Plants Inoculated with Trichoderma Strains and Metabolites. Microorganisms 2022, 10, 87. https://doi.org/10.3390/ microorganisms10010087

Academic Editor: Gary A. Strobel

Received: 13 December 2021

Accepted: 30 December 2021

Published: 31 December 2021

Publisher's Note: MDPI stays neutral with regard to jurisdictional claims in published maps and institutional affiliations.

Copyright: (c) 2021 by the authors Licensee MDPI, Basel, Switzerland. This article is an open access article distributed under the terms and conditions of the Creative Commons Attribution (CC BY) license (https:// creativecommons.org/licenses/by/ $4.0 /)$.
1 Department of Agricultural Sciences, University of Naples Federico II, 80055 Portici, Italy; nadia.lombardi@unina.it (N.L.); alessandro.piccolo@unina.it (A.P.)

2 Center for Studies on Bioinspired Agro-Environmental Technology (BAT Center), University of Naples Federico II, 80138 Naples, Italy; woo@unina.it

3 Interdepartmental Research Centre on Nuclear Magnetic Resonance (NMR) for the Environment, Agro-Food and New Materials (CERMANU), University of Naples Federico II, 80055 Portici, Italy

4 Department of Plant Sciences, University of Saskatchewan, Saskatoon, SK S7N5A8, Canada; navid.bazghaleh@usask.ca (N.B.); pratibha.prashar@usask.ca (P.P.); bert.vandenberg@usask.ca (A.V.)

5 Department of Pharmacy, University of Naples Federico II, 80131 Naples, Italy

6 National Research Council, Institute for Sustainable Plant Protection, 80055 Portici, Italy

* Correspondence: robmarra@unina.it; Tel.: +39-081-253-2253

\begin{abstract}
Biofortification of crops via agricultural interventions represents an excellent way to supply micronutrients in poor rural populations, who highly suffer from these deficiencies. Soil microbes can directly influence plant growth and productivity, e.g., by contrasting plant pathogens or facilitating micronutrient assimilation in harvested crop-food products. Among these microbial communities, Trichoderma fungi are well-known examples of plant symbionts widely used in agriculture as biofertilizers or biocontrol agents. In this work, eleven Trichoderma strains and/or their bioactive metabolites (BAMs) were applied to lentil plants to evaluate their effects on plant growth and mineral content in greenhouse or field experiments. Our results indicated that, depending upon the different combinations of fungal strain and/or BAM, the mode of treatment (seed and/or watering), as well as the supplementary watering with solutions of iron $(\mathrm{Fe})$ and $\mathrm{zinc}(\mathrm{Zn})$, the mineral absorption was differentially affected in treated plants compared with the water controls. In greenhouse conditions, the largest increase in Fe and Zn contents occurred when the compounds were applied to the seeds and the strains (in particular, T. afroharzianum T22, T. harzianum TH1, and T. virens GV41) to the soil. In field experiments, Fe and Zn contents increased in plants treated with T. asperellum strain KV906 or the hydrophobin HYTLO1 compared with controls. Both selected fungal strains and BAMs applications improved seed germination and crop yield. This biotechnology may represent an important challenge for natural biofortification of crops, thus reducing the risk of nutrient deficiencies.
\end{abstract}

Keywords: lentil; biofortification; Trichoderma; bioactive metabolites; mineral content; iron; zinc

\section{Introduction}

The FAO estimates that by 2050 the world population will reach 9.1 billion people and food production should increase by $70 \%$ [1]. However, the availability of agricultural land is reducing more and more, and many of the natural resources currently used by humans show signs of degradation or pollution. Moreover, basic crops (i.e., rice, wheat, corn), the main food in diets of the poorest populations, contain limited amounts of micronutrients, including minerals (iron, zinc, iodine, selenium, etc.) and vitamins, thus not guaranteeing the recommended daily requirements $[2,3]$.

The spread of micronutrient malnutrition (MNM), a chronic shortage of minerals and vitamins, has serious socio-economic consequences, both individually and collectively $[3,4]$. This "hidden hunger" is known to induce diseases and disorders in both developed and 
developing nations and is currently considered as one of the most serious challenges that faces humanity [3,5]. Indeed, interventions to reduce micronutrient deficiencies were listed in the Copenhagen consensus as the number one priority, in agreement with the Sustainable Development Goal 2 (SDG2) established by the United Nations in 2015 [6].

MNM can be effectively countered in different ways, e.g., by encouraging dietary diversification, by supplementing micronutrients in the form of pills or enriched processed foods or through biofortification, intended as the increase in bioavailable micronutrients in the edible parts of staple crops. The latter comprises conventional plant breeding techniques, agronomic approaches, as well as genetic engineering methods [2,7]. Several studies have shown the positive effects of consuming biofortified crops to contrast hidden hunger also in the long-term [8]. However, each strategy has advantages and disadvantages, and the results are often limited by infrastructures, regulations, and costs $[9,10]$.

Agronomic biofortification may offer novel opportunities to both increase the micronutrients content in crops and reduce the use of chemical fertilizers, which represent a cost to farmers and pose a risk to the human health and environment. A novel method to increase the bioavailability of important micronutrients to the plant consists of the inoculation with beneficial microorganisms that can favor the solubilization, absorption, and assimilation of these compounds by the plant [11,12]. These include endophytic fungi and yeasts, that enhance plant growth directly by improving plant nutrition and are largely applied as biofertilizers worldwide [13,14]. Moreover, indirect beneficial effects of endophytic colonization include resistance induction, tolerance towards biotic and abiotic stresses, production of antimicrobial and useful compounds, etc. [14]. Among plant growth-promoting microbes (PGPM), several species of the genus Trichoderma have proven ability to establish symbiotic relationships with host plants [15]. Trichoderma are soil fungi recognized as beneficial biological control agents against plant pathogens for more than 70 years. At present, they are recognized as active ingredients in more than 250 agricultural products marketed worldwide as biological pesticides, fertilizers, plant growth enhancers and stimulants of natural resistance, as well as soil amendments/inoculants [16]. An increasing number of studies are reporting the effectiveness of new species or isolates of Trichoderma to improve plant fitness under abiotic stresses [17], activate plant defense responses [18], stimulate crop productivity and nutrient content [19-21] or control plant pathogens [15]. These effects have been also related to the production of Trichoderma bioactive metabolites (BAMs), that can be used either alone or in combination with the living microbe [22].

The aim of this work was to use a technology based on microbial fungal organisms and/or their extracts to augment the nutritional value, specifically to increase the mineral content, in an important legume crop, such as lentil (Lens culinaris L.). Legumes are key sources of dietary proteins and their consumption has numerous positive effects on health, including reduced risk of several chronic diseases, improvement of the digestive function, and prevention of obesity [23]. Therefore, we tested the effects of biocontrol agents, such as fungi of the genus Trichoderma, and/or their bioactive metabolites (BAMs), on the uptake capacity of important minerals in a lentil variety that is most widely cultivated throughout the world. The bioformulations were applied under different conditions and in diverse combinations in order to identify and select a treatment that may be effectively applied to the crop in question for mineral biofortification. Furthermore, the effects of the different treatments in terms of promotion of plant growth and yield increase were evaluated.

\section{Materials and Methods}

\subsection{Plant Material}

Lentil (Lens culinaris L.) variety CDC MAXIM CL was used for the experiments. The characteristics of this variety of red lentil, which is among the most cultivated varieties in the world, are summarized in Table 1. 
Table 1. Characteristics of lentil (Lens culinaris L.) variety CDC MAXIM CL used in this study [24].

\begin{tabular}{cc}
\hline Variety & CDC MAXIM CL \\
\hline Seed color & Red \\
\hline Seed dimension & Small \\
\hline Maximun yield (\%) & 100 \\
\hline Height (cm) & 34 \\
\hline Flowering (days) & 51 \\
\hline Seed weight (g/1000) & 40 \\
\hline Aschochyta Resistance & Good \\
\hline Anthracnose resistance (Race 1) & Good \\
\hline
\end{tabular}

\subsection{Fungal Strains and Metabolites}

Pure cultures of 11 Trichoderma strains, including T. harzianum strain TH1 (TH1), T. harzianum strain M10 (M10), T. longibrachiatum strain MK1 (MK1), T. atroviride strain P1 (P1), T. afroharzianum strain T22 (T22; formerly T. harzianum), T. asperellum strain T53 (T53), T. harzianum strain HK2 (HK2), T. harzianum strain HK5 (HK5), T. asperellum strain CRN1 (CRN1), T. asperellum strain KV906 (KV906), and T. virens strain GV41 (GV41) were obtained from the collection available at the Department of Agricultural Sciences of the University of Naples Federico II, Italy (Table 2). Fungal cultures were cultivated on Petri plates at $25{ }^{\circ} \mathrm{C}$ containing Potato Dextrose Agar (PDA, HiMedia Laboratories, Mumbai, India). After 7-10 d, the spores were collected, and the concentration of conidial suspensions was determined using a counting chamber. Fungal cultures were identified by microbiological and molecular techniques. The strains used in this work were selected according to their biocontrol and/or plant growth promotion activities as determined in previous experiments carried out in our laboratory.

Table 2. List of Trichoderma species and strains used for the experiments.

\begin{tabular}{|c|c|c|c|}
\hline No. & Trichoderma Species & Strain & Origin \\
\hline 1 & harzianum & TH1 & Italy \\
\hline 2 & harzianum & M10 & Australia \\
\hline 3 & longibrachiatum & MK1 & Italy \\
\hline 4 & atroviride & P1 & Norway \\
\hline 5 & afroharzianum & T22 & USA \\
\hline 6 & asperellum & T53 & Spain \\
\hline 7 & harzianum & HK2 & USA \\
\hline 8 & harzianum & HK5 & USA \\
\hline 9 & asperellum & CRN1 & Costa Rica \\
\hline 10 & asperellum & KV906 & Brazil \\
\hline 11 & virens & GV41 & USA \\
\hline
\end{tabular}

In this work, three different Trichoderma metabolites were used (Table 3): (i) 6-Pentylalpha-pyrone (6PP) isolated from T. atroviride strain P1 (yield $84 \mathrm{mg} / \mathrm{L}$ of culture filtrate), which has been previously described for its activity and role in plant growth promotion [25]. (ii) Harzianic acid (HA) produced by T. harzianum strain M10 (yield $98 \mathrm{mg} / \mathrm{L}$ of culture filtrate), which is a tetramic acid with proven capability to bind iron, stimulate plant growth, and exert antifungal activity [26,27]. Previous results indicated that this metabolite acts as a siderophore causing iron precipitation [28]. (iii) The hydrophobin HYTLO1, a small protein $(8 \mathrm{kDa})$ secreted by T. longibrachiatum strain MK1. This protein is involved in the formation of aerial mycelium, has antifungal activity, and is able to stimulate plant defense to pathogen attack, as well as root growth [28]. These compounds were extracted and characterized as previously described [25-28]. BAM solutions were prepared by diluting the compound with distilled water to the final concentration used for the treatments [21]. 
For HA and $6 \mathrm{PP}, 0.1 \%$ ethyl acetate was added to facilitate resuspension and successively evaporated under cabinet flow.

Table 3. Trichoderma bioactive metabolites (BAMs) used in this work.

\begin{tabular}{ccccc}
\hline Metabolite & Chemical Feature & Source & Properties & Reference \\
\hline $\begin{array}{c}\text { 6-pentyl-alpha-pyrone } \\
\text { (6PP) }\end{array}$ & Pyrone & T. atroviride strain P1 & $\begin{array}{c}\text { Antibiotic, volatile compound } \\
\text { with a characteristic smell of } \\
\text { coconut. }\end{array}$ & [25] \\
\hline Harzianic acid (HA) & Tetramic acid & T. harzianum strain M10 & $\begin{array}{c}\text { Antifungal activity, promotion of } \\
\text { plant growth, ability to bind iron. }\end{array} \quad$ [26,27] \\
\hline HYTLO1 & Hydrophobin & $\begin{array}{c}\text { T. longibrachiatum strain } \\
\text { MK1 }\end{array}$ & $\begin{array}{c}\text { Involved in the aerial mycelium } \\
\text { formation and stimulation of plant } \\
\text { defenses and root growth, } \\
\text { antifungal activity. }\end{array}$ \\
\hline
\end{tabular}

\subsection{Experimental Design}

For each experiment, lentil seeds were previously sterilized by immersion in $1 \%(v / v)$ sodium hypochlorite solution for $5 \mathrm{~min}$, followed by repeated washes in sterile distilled water. Then, the seeds were immersed in a solution of ethanol $(70 \%, v / v)$ for 5 min to promote germination.

Fungal strains or BAMs were applied to: (i) The seeds by dipping in Trichoderma spore suspensions or metabolite solutions. Seeds were left in Petri plates under laminar flow hood until the solutions were fully absorbed. The controls consisted of water-treated seeds. (ii) The soil by watering in proximity of the root crown. Seven days after the treatment, $50 \%$ of the plants were watered with a solution containing Fe and $\mathrm{Zn}$ (1X FeZn solution), consisting of $27.8 \mathrm{mg} / \mathrm{L}$ iron sulfate heptahydrate and $8.6 \mathrm{mg} / \mathrm{L}$ zinc sulfate heptahydrate, respectively. Higher mineral contents $(2 X, 5 X, 10 X)$ were obtained by proportionally increasing the Fe and $\mathrm{Zn}$ concentrations. The remaining plants were watered only with water. Detailed protocols used in each experiment are reported below.

\subsubsection{EXPERIMENT \#A: Application of Trichoderma Strains or BAMs in Greenhouse}

The seeds were treated with a spore suspension $\left(1 \times 10^{7} \mathrm{sp} / \mathrm{mL}\right)$ of different Trichoderma strains (M10, P1 or T22) or with a solution of the secondary metabolites HA or 6PP (both at $10^{-6} \mathrm{M}$ ). The seeds were placed to germinate in pots of $14 \mathrm{~cm}$ diameter containing sterile soil (10 seeds per pot with three replicates for each treatment) and after $3 \mathrm{~d}$ the percentage of germination was evaluated. The pots were setup in a completely randomized design, and the plants were grown under greenhouse conditions (day/night temperature $25 / 15{ }^{\circ} \mathrm{C}$; humidity 50-60\%; day length 12-14 h) and watered when necessary. About 4 weeks after sowing, a first soil watering with $25 \mathrm{~mL} /$ pot of the same solutions containing the spores or the BAMs used for seed treatments was carried out. After $7 \mathrm{~d}, 50 \%$ of the plants were treated with $25 \mathrm{~mL} /$ pot of $1 \mathrm{X}$ FeZn solution and the remaining plants with water (Table S1). Plants were harvested 2 weeks later and the pods containing lentil seeds were collected for further analyses.

\subsubsection{EXPERIMENT \#B: Application of Trichoderma Strains in Greenhouse}

In this experiment, 11 strains of Trichoderma, previously selected and characterized (par. 2.2), were used. The treatments consisted of two applications of spore suspensions $\left(1 \times 10^{7} \mathrm{sp} / \mathrm{mL}\right)$ dissolved in water, first to the seeds and then, 4 weeks later, to the soil. Water treatments served as controls. After $7 \mathrm{~d}$, another soil watering was carried out using 1X FeZn solution, prepared as described above. The experimental conditions (number of seeds per pot, replicates per treatment, etc.) were the same as in experiment \#A. Plants were harvested 2 weeks later and the pods containing lentil seeds were collected for further analyses. 
2.3.3. EXPERIMENT \#C: Trichoderma Strains and/or BAMs Applied Singly or Combined in Greenhouse

In this experiment, Trichoderma strains (T22, TH1, GV41) and metabolites (HA, 6PP, HYTLO1) were applied singly to the seeds (Table S2). The metabolites HA and 6PP were both used at a final concentration of $10^{-6} \mathrm{M}$, while HYTLO1 was used at $10^{-8} \mathrm{M}$. Watercoated seeds served as controls. The seeds were placed in $14 \mathrm{~cm}$ diameter pots filled with sterile soil. In each pot, seven seeds were sowed, with three replicates per treatment. The pots were setup in a completely randomized design, and the plants were grown under greenhouse conditions (day/night temperature $25 / 15^{\circ} \mathrm{C}$; humidity $50-60 \%$; day length $12-14 \mathrm{~h}$ ) and watered when necessary. The first soil watering was made 2 months after sowing, using $35 \mathrm{~mL}$ of solution per pot. After $7 \mathrm{~d}, 50 \%$ of the plants were treated with $35 \mathrm{~mL}$ of 1X FeZn solution and the remaining plants with water (Table S2).

\subsubsection{EXPERIMENT \#D: Plant Treatments in Field Conditions}

A field experiment was performed in a trial at the Department of Agricultural Sciences of the University of Naples Federico II located in Portici (Naples, Italy). The plot size was approximately $15 \times 7 \mathrm{~m}$. The soil of the site was clay loam with $\mathrm{pH}$ (1:2.5 soil:water) 4.8, non-saline [EC(1:2.5 soil:water) $0.3 \mathrm{dS} / \mathrm{m}$ ], and with cation exchange capacity of $13.57 \mathrm{cmol}$ $(\mathrm{p}+) / \mathrm{kg}$. The experimental soil contained $1.5 \%$ organic carbon, available nitrogen $(\mathrm{N}$; $296 \mathrm{~kg} / \mathrm{ha}$ ), available phosphorus (P; $27 \mathrm{~kg} / \mathrm{ha})$, and available potassium (K; $278.16 \mathrm{~kg} / \mathrm{ha})$. The climate of the region is Mediterranean. The experimental site is located at $40.81^{\circ} \mathrm{N}$ latitude, $14.34^{\circ} \mathrm{E}$ longitude, and $47 \mathrm{~m}$ above the mean sea level. A commercial nodulating bioformulate based on selected nitrogen fixing rhizobia (Umostart, Sipcam, Italy) was applied according to the manufacturer's instructions. The formulation consists of a consortium of Bradyrhizobium japonicum, Rhizobium melioti, and Rhizobium leguminosarum bv. viciae, in addition to a nutritional substrate that promotes root development at an early stage.

Lentil seeds were coated with $500 \mu \mathrm{L}$ of Trichoderma spore suspensions (from strains TH1, M10, P1, T22, T53, HK5, CRN1, KV906 or GV41) or metabolite solutions (HA, 6PP or HYTLO1). Trichoderma spore suspensions were used at $1 \times 10^{7}$ spore $/ \mathrm{mL}$. The metabolites HA and 6PP were both used at a final concentration of $10^{-6} \mathrm{M}$, while HYTLO1 was used at $10^{-8} \mathrm{M}$. The seeds were germinated in polystyrene boxes. Each treatment consisted of 10 plants, with three biological replicates. After $10 \mathrm{~d}$, the seedlings were transplanted into soil, with $15 \mathrm{~cm}$ plant intervals, while $50 \mathrm{~cm}$ distance was used to avoid contaminations among the treatments. For the combined application [T22 + HA], the metabolite was added to the spore suspension at the time of inoculation. The crop was harvested at physiological maturity after 4 months.

\subsection{Plant Analysis}

Plant samples consisted of lentil pods containing the seeds. The growth and yield parameter measured included: Seed germination (\%), plant dry weight ( $\mathrm{g} /$ plant), and seed weight ( $\mathrm{g} /$ plant).

Determination of Mineral Content

In this work, the analysis of the mineral content $(\mathrm{Fe}, \mathrm{Zn})$ of lentil samples was carried out on mineralized samples, as described by [29]. The samples were dried in an oven $\left(60^{\circ} \mathrm{C}\right)$ for about 3 days (until complete dehydration), and subsequently were finely ground in a pulverizer, using a cycle of $5 \mathrm{~min}$ at a speed of $550 \mathrm{rpm}$. For each sample, $500 \mathrm{mg}$ of powder were transferred into porcelain crucibles and incinerated in a muffle furnace at $500{ }^{\circ} \mathrm{C}$ for $4 \mathrm{~h}$. The resulting ash, once cooled, was dissolved in $5 \mathrm{~mL}$ of nitric acid $\left(\mathrm{HNO}_{3}\right.$, diluted 1:3, $v / v$ ) and boiled until complete evaporation of the acid solution. The samples were placed again in muffle at $500{ }^{\circ} \mathrm{C}$ for $1 \mathrm{~h}$ and then left to cool. Then, $5 \mathrm{~mL}$ of hydrochloric acid $(\mathrm{HCl}$, diluted $1: 3, v / v)$ and $15 \mathrm{~mL}$ of MilliQ grade water were added and the solution was boiled for $2 \mathrm{~min}$ and filtered (Macherey-Nagel MN640d filters) to remove any corpuscular particles that may interfere with the analysis. The filtered solution was collected in $25 \mathrm{~mL}$ 
flasks and brought to volume with MilliQ water. The resulting solutions were stored at $4{ }^{\circ} \mathrm{C}$ until analyzed.

The mineral content of the samples was determined by Atomic Absorption Spectroscopy, using the device AAnalyst 700 (Perkin-Elmer, Waltham, MA, USA). For each item analyzed, appropriate calibration curves were constructed using commercial standard solutions (Figure S1). All of the measurements were carried out using the operating flame standard conditions recommended by the manufacturer. Each measurement is the average of three consecutive readings taken by the instrument in succession. Three biological replicates were analyzed for each sample. For all of the samples, the glassware was washed with an aqueous solution of $2 \%(v / v) \mathrm{HNO}_{3}$.

\subsection{Statistical Analysis}

All of the obtained data were analyzed by one-way ANOVA using SPSS 15.0 software (SPSS, Inc., Chicago, Illinois), and significant differences among the treatments were separated using S-N-K (Student- Newman-Keuls) and Fisher's Least Significant Difference (LSD) post hoc tests at the 0.05 level of significance.

\section{Results}

\subsection{Effects of Trichoderma Strains or BAMs on Lentil Plants in Greenhouse (\#Experiment A)}

Our results indicated that the application of Trichoderma strains or metabolites to lentil plants affected the assimilation of minerals in the plant. Depending upon the different combinations of fungal strain and/or BAM, the mode of treatment (seed and/or watering), as well as the supplementary watering with FeZn solution, the mineral absorption in the treated plants varied as compared with the water controls. Preliminary experiments showed that the biocontrol agent T. afroharzianum strain T22 applied as a seed-coating produced an increase in iron and zinc contents of lentil plants watered with a FeZn solution (data not shown). Higher concentrations (2X, 5X or 10X) of FeZn solution did not ensure a proportional accumulation of these minerals in the treated samples. In addition, the highest concentration (10X) showed phytotoxic effects on plants when applied in combination with the Trichoderma strain. Therefore, the $1 \mathrm{X} \mathrm{FeZn} \mathrm{solution} \mathrm{was} \mathrm{used} \mathrm{in} \mathrm{subsequent} \mathrm{experiments.}$

Seed treatments followed by soil watering with strain or metabolite solutions determined an increase in plant development when lentil plants were grown in greenhouse. The growth and physiology of the treated plants were enhanced, with a greater ability to flower and produce fruits. The treated plants were greener and demonstrated a prolonged development compared with the untreated controls, which appeared to have an advanced state of senescence (Figure 1). In addition, the metabolites HA and 6PP determined the highest increase in iron content in treated plants compared with controls when plants were watered with the FeZn solution (Figure 2). No effect was observed in zinc content in the treated plants compared with controls.

\subsection{Effects of Trichoderma Strains on Lentil Plants in Greenhouse (\#Experiment B)}

Applications of different Trichoderma strains in greenhouse affected both crop productivity and mineral content. Compared with the untreated control, all of the strains determined a significant increase $(p<0.05)$ in fresh weight of the harvested pods (Figure 3 ). Highest increases $(p<0.01)$ in crop yield were observed after the treatments with strains TH1, P1, and GV41. Moreover, several strains were able to increase the content of iron (T22, TH1, and GV41) and zinc (T22) in the treated lentils (Table 4).

\subsection{Effects of Trichoderma Strains or BAMs Applied Singly or Combined (\#Experiment C)}

Based on these data, the strains that showed the best performances were applied singly or combined in greenhouse (exp. \#C, par. 2.3.3). The seed treatment with Trichoderma spores or BAMs differently affected germination at 3 days after sowing (Figure 4). Trichoderma strains T22 and TH1 significantly $(p<0.05)$ increased about $70 \%$ of germinated seeds as compared with water controls. Similarly, the seeds coated with the metabolite HA or 
HYTLO1 solutions showed, respectively, about 60 and 50\% higher germination vs. control (Figure 4).

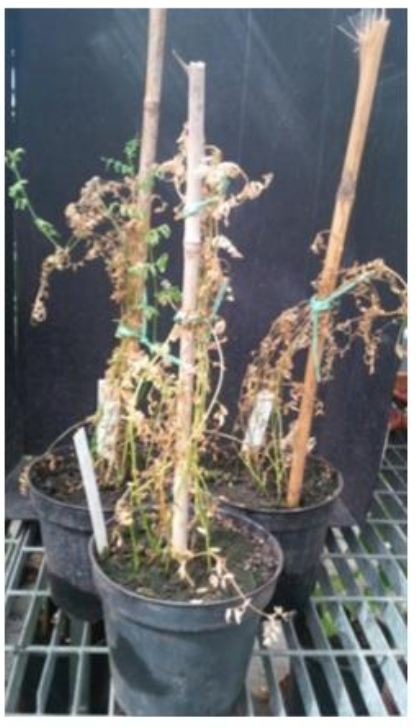

Control

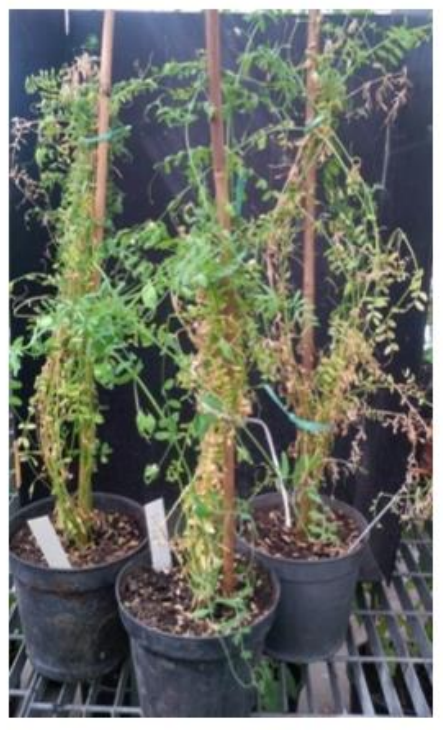

T22

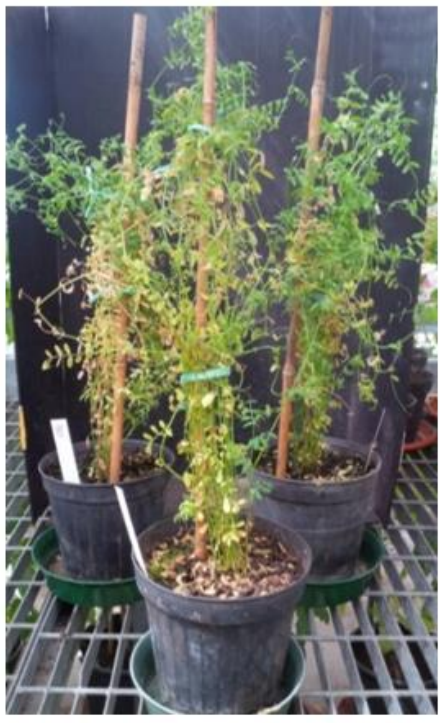

P1

Figure 1. Development of lentil plants treated with various Trichoderma strains. (Left) Control (water) untreated. (Center) Plants treated with T. afroharzianum strain T22. (Right) Plants treated with the strain P1 of T. atroviride.

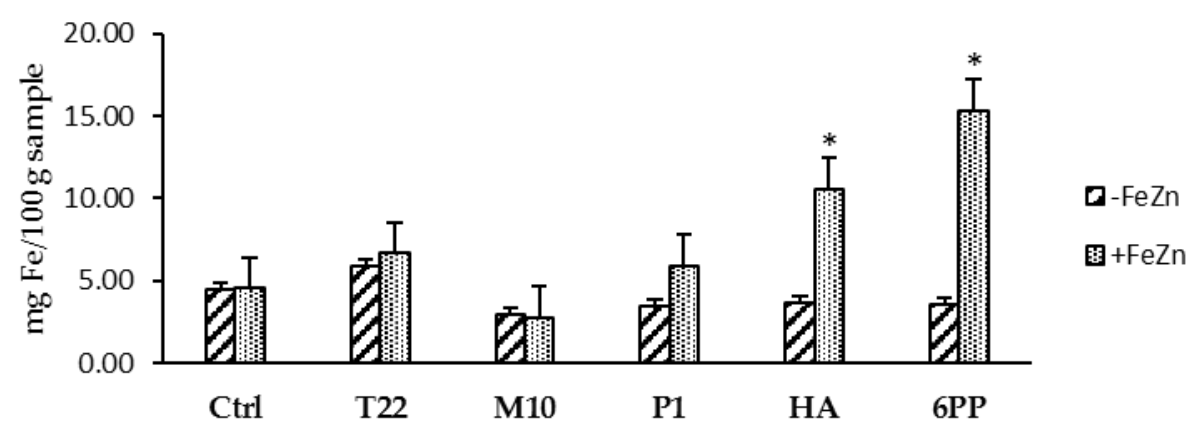

Figure 2. Iron content in lentil plants treated with Trichoderma strains (T22, M10 or P1) or metabolites (HA or 6PP) to the seeds and to the soil (1st watering). Water treatments served as controls (Ctrl). Data represent the mean value of three biological replicates \pm standard error. The second soil watering was performed with a $1 \mathrm{X}$ solution of iron and zinc $(+\mathrm{FeZn})$ or water $(-\mathrm{FeZn})$. Asterisks indicate significant differences $(p<0.05)$ compared with the control. Statistical analysis was carried out using the one-way ANOVA.

When singly or combined applications of Trichoderma strains and BAMs were carried out in greenhouse, significant increases in mineral content occurred, particularly when plants were supplemented with a FeZn solution. In single treatments (strains/metabolites and water or vice versa), the highest increases in iron content were observed when the strain TH1 was applied to the seed (treatment $\mathrm{TH} 1 / \mathrm{H}_{2} \mathrm{O}$; Table 5) or when the BAMs 6PP or HYTLO1 were watered to the soil (treatments $\mathrm{H}_{2} \mathrm{O} / 6 \mathrm{PP}$ and $\mathrm{H}_{2} \mathrm{O} / \mathrm{HYTLO} 1$, respectively; Table 5). In the absence of supplementation with the FeZn solution (-FeZn), significant $(p<0.05)$ increases in iron content were observed only when strains T22 or GV41 were applied as soil watering (treatments $\mathrm{H}_{2} \mathrm{O} / \mathrm{T} 22$ and $\mathrm{H}_{2} \mathrm{O} / \mathrm{GV} 41$, respectively; Table 5). In the case of zinc content, treatments $\mathrm{H}_{2} \mathrm{O} / \mathrm{T} 22$ and $\mathrm{H}_{2} \mathrm{O} / \mathrm{HA}$ gave significant differences compared with water controls (in the absence of FeZn supplementation). Unfortunately, after germination, all of the $\mathrm{T} 22 / \mathrm{H}_{2} \mathrm{O}$-treated plants supplemented with FeZn solution died. Therefore, their mineral content was not determined (Table 5). 


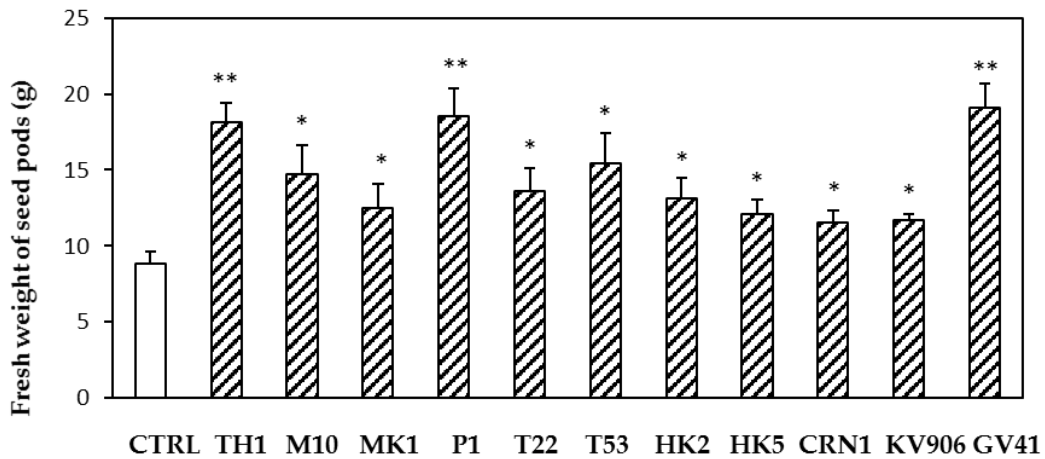

Figure 3. Effects of treatments based on different Trichoderma strains (TH1, M10, MK1, P1, T22, T53, HK2, HK5, CRN1, KV906, GV41) on the yield of lentil plants (expressed as fresh weight of seed pods per treatment). Data represent the mean value of three biological replicates \pm standard error. The treatments consisted of two applications of spore suspensions, first to the seeds and then, 4 weeks later, to the soil. Water treatments served as controls (CTRL). After $7 \mathrm{~d}$, another soil watering was carried out using the $1 \mathrm{X}$ FeZn solution. Asterisks indicate significant differences $\left({ }^{*} p<0.05 ;{ }^{* *} p<0.01\right)$ compared with the control. Statistical analysis was carried out using the one-way ANOVA.

Table 4. Effects of Trichoderma strains (TH1, M10, MK1, P1, T22, T53, HK2, CRN1, KV906, GV41) on the lentil mineral content. Water treatments served as controls (CTRL). Data represent the mean value of three biological replicates \pm standard deviation (SD). Different letters in a column indicate statistically significant differences for $p<0.05$.

\begin{tabular}{ccc}
\hline & \multicolumn{2}{c}{ Mineral Content (mg/100 g Sample) } \\
\hline Strain & Fe & Zn \\
\hline TH1 & $5.82 \pm 0.65 \mathrm{bd}$ & $7.345 \pm 0.84 \mathrm{a}$ \\
M10 & $4.02 \pm 0.41 \mathrm{a}$ & $7.245 \pm 0.80 \mathrm{a}$ \\
MK1 & $2.77 \pm 0.28 \mathrm{c}$ & $7.695 \pm 0.69 \mathrm{a}$ \\
P1 & $4.75 \pm 0.39 \mathrm{ad}$ & $6.845 \pm 0.77 \mathrm{c}$ \\
T22 & $6.47 \pm 0.45 \mathrm{~b}$ & $9.395 \pm 0.85 \mathrm{~b}$ \\
T53 & $3.99 \pm 0.52 \mathrm{a}$ & $7.295 \pm 0.64 \mathrm{a}$ \\
HK2 & $4.42 \pm 0.68 \mathrm{a}$ & $7.345 \pm 0.25 \mathrm{a}$ \\
HK5 & $4.01 \pm 0.54 \mathrm{a}$ & $7.245 \pm 0.84 \mathrm{a}$ \\
CRN1 & $3.15 \pm 0.27 \mathrm{c}$ & $7.745 \pm 0.67 \mathrm{a}$ \\
KV906 & $4.22 \pm 0.51 \mathrm{a}$ & $7.545 \pm 0.64 \mathrm{a}$ \\
GV41 & $6.88 \pm 0.52 \mathrm{~b}$ & $7.695 \pm 0.34 \mathrm{a}$ \\
Control & $4.00 \pm 0.63 \mathrm{a}$ & $7.995 \pm 0.40 \mathrm{a}$ \\
\hline
\end{tabular}

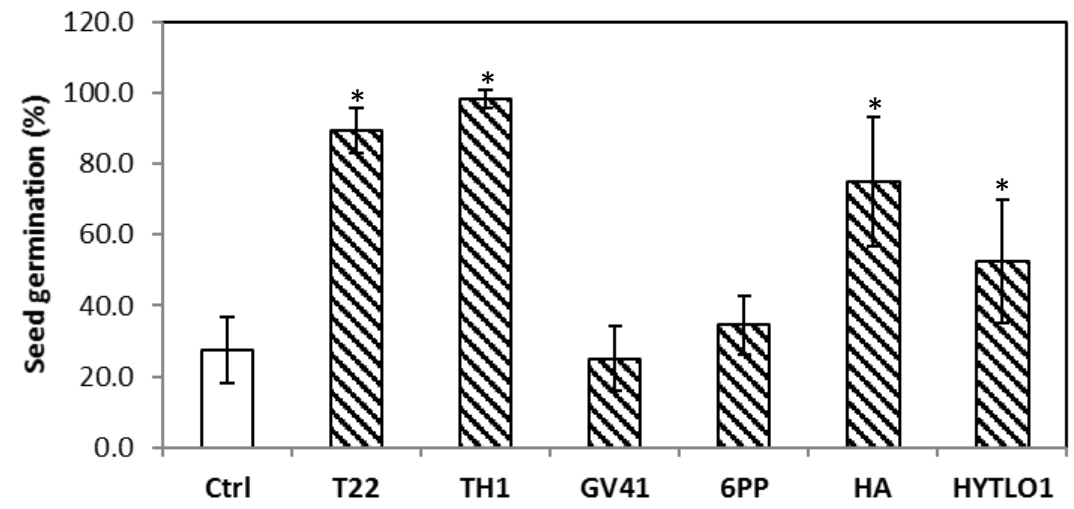

Figure 4. Effect of the seed treatment with Trichoderma strains (T22, TH1, GV41) or metabolites (6PP, HA, HYTLO1) on the germination of lentil seeds cv. CDC MAXIM CL (3 days after the treatment). Water treatments served as controls (Ctrl). Asterisks indicate significant differences $(p<0.05)$ compared with the control. Statistical analysis was carried out using the one-way ANOVA. 
Table 5. Effects of Trichoderma strains (T22, TH1, GV41) or metabolites (HA, 6PP, HYTLO1), applied singly, on the lentil mineral content. Water treatments served as controls (CTRL). Treatments were applied to the seed (indicated on the left), then to the soil (indicated on the right). After $7 \mathrm{~d}$ from the soil treatment, another soil watering was carried out using the $1 \mathrm{X}$ FeZn solution $(+\mathrm{FeZn})$ or water $(-\mathrm{FeZn})$. Data represent the mean value of three biological replicates \pm standard deviation (SD). Different letters in a column indicate statistically significant differences for $p<0.05$; nd: Not determined.

\begin{tabular}{|c|c|c|c|c|c|c|c|c|}
\hline \multirow{3}{*}{ Treatment Applied to Seed/Soil } & \multicolumn{8}{|c|}{ Mineral Content (mg/100 g Sample) } \\
\hline & \multicolumn{4}{|c|}{ IRON CONTENT } & \multicolumn{4}{|c|}{ ZINC CONTENT } \\
\hline & \multicolumn{2}{|c|}{$-\mathrm{FeZn}$} & \multicolumn{2}{|c|}{$+\mathrm{FeZn}$} & \multicolumn{2}{|c|}{$-\mathrm{FeZn}$} & \multicolumn{2}{|c|}{$+\mathrm{FeZn}$} \\
\hline CTRL & 5.60 & $\pm 0.41 \mathrm{a}$ & 12.06 & $\pm 0.84 \mathrm{a}$ & 6.00 & $\pm 0.62 \mathrm{a}$ & 4.28 & $\pm 0.45 \mathrm{a}$ \\
\hline $\mathrm{H}_{2} \mathrm{O} / \mathrm{T} 22$ & 13.59 & $\pm 1.63 \mathrm{~b}$ & 4.57 & $\pm 0.35 \mathrm{~b}$ & 7.95 & $\pm 0.84 \mathrm{~b}$ & 3.81 & $\pm 0.25 \mathrm{a}$ \\
\hline $\mathrm{H}_{2} \mathrm{O} / \mathrm{TH} 1$ & 4.21 & $\pm 0.58 \mathrm{c}$ & 4.55 & $\pm 0.65 \mathrm{~b}$ & 6.31 & $\pm 0.36 \mathrm{a}$ & 4.62 & $\pm 0.41 \mathrm{a}$ \\
\hline $\mathrm{H}_{2} \mathrm{O} / \mathrm{GV} 41$ & 13.88 & $\pm 1.28 \mathrm{~b}$ & 10.77 & $\pm 0.96 \mathrm{a}$ & 4.85 & $\pm 0.58 \mathrm{a}$ & 4.46 & $\pm 0.56 \mathrm{a}$ \\
\hline $\mathrm{H}_{2} \mathrm{O} / \mathrm{HA}$ & 7.13 & $\pm 0.63 \mathrm{~d}$ & 7.21 & $\pm 0.78 \mathrm{c}$ & 7.52 & $\pm 0.89 \mathrm{ab}$ & 4.28 & $\pm 0.69 \mathrm{a}$ \\
\hline $\mathrm{H}_{2} \mathrm{O} / 6 \mathrm{PP}$ & 4.38 & $\pm 0.48 \mathrm{c}$ & 24.99 & $\pm 1.96 \mathrm{~d}$ & 6.40 & $\pm 0.54 \mathrm{a}$ & 4.47 & $\pm 0.85 \mathrm{a}$ \\
\hline $\mathrm{H}_{2} \mathrm{O} / \mathrm{HYTLO} 1$ & 3.36 & $\pm 0.36 \mathrm{c}$ & 47.89 & $\pm 1.84 \mathrm{e}$ & 5.82 & $\pm 0.23 \mathrm{a}$ & 3.79 & $\pm 0.55 \mathrm{a}$ \\
\hline $\mathrm{T} 22 / \mathrm{H}_{2} \mathrm{O}$ & 5.56 & $\pm 0.69 \mathrm{ac}$ & nd & & 4.90 & $\pm 0.85 \mathrm{a}$ & nd & \\
\hline $\mathrm{TH} 1 / \mathrm{H}_{2} \mathrm{O}$ & 7.73 & $\pm 0.36 \mathrm{~d}$ & 19.53 & $\pm 2.65 \mathrm{~d}$ & 5.53 & $\pm 0.96 \mathrm{a}$ & 5.29 & $\pm 0.98 \mathrm{a}$ \\
\hline $\mathrm{GV} 41 / \mathrm{H}_{2} \mathrm{O}$ & 5.73 & $\pm 0.44 \mathrm{a}$ & 2.81 & $\pm 0.24 \mathrm{f}$ & 6.08 & $\pm 0.65 \mathrm{a}$ & 4.04 & $\pm 0.63 \mathrm{a}$ \\
\hline $\mathrm{HA} / \mathrm{H}_{2} \mathrm{O}$ & 7.76 & $\pm 0.18 \mathrm{~d}$ & 5.51 & $\pm 0.75 \mathrm{c}$ & 5.69 & $\pm 0.41 \mathrm{a}$ & 5.13 & $\pm 0.35 \mathrm{a}$ \\
\hline $6 \mathrm{PP} / \mathrm{H}_{2} \mathrm{O}$ & 9.13 & $\pm 0.85 \mathrm{e}$ & 8.57 & $\pm 0.96 \mathrm{cg}$ & 6.93 & $\pm 0.21 \mathrm{a}$ & 4.56 & $\pm 0.14 \mathrm{a}$ \\
\hline HYTLO1 $/ \mathrm{H}_{2} \mathrm{O}$ & 7.02 & $\pm 1.00 \mathrm{ad}$ & 9.94 & $\pm 1.45 \mathrm{ag}$ & 6.61 & $\pm 0.36 \mathrm{a}$ & 5.01 & $\pm 0.56 \mathrm{a}$ \\
\hline
\end{tabular}

In the same experiment, the effects of combined applications of Trichoderma BAMs to the seeds/spores and to the soil on the lentil mineral content were evaluated (Table 6). The iron content increased significantly $(p<0.05)$ in plants whose seeds were treated with HA, $6 \mathrm{PP}$ or HYTLO1, and then watered, respectively, with water, T22 or G41 and TH1, in the absence of FeZn supplementation (treatments $\mathrm{HA} / \mathrm{H}_{2} \mathrm{O}, 6 \mathrm{PP} / \mathrm{H}_{2} \mathrm{O}, 6 \mathrm{PP} / \mathrm{T} 22$, 6PP/GV41, HYTLO1/TH1; Table 6). Conversely, the iron content quadruplicated when the combined treatments HA/GV41 and 6PP/GV41 were used, followed by 1X FeZn watering (Table 6). Only the seeds coated with HA or HYTLO1 that were successively watered with water and GV41 spores, respectively, in addition to the $1 \mathrm{X}$ FeZn solution, revealed a significant increase in zinc content compared with controls (Table 6). Overall, the supplementation with 1X FeZn solution increased the content of iron in treated plants, while an opposite trend was found in the case of zinc (Table 6).

\subsection{Effects of Trichoderma Strains and/or BAMs on Lentil Plants in Field Conditions (\#Experiment D)}

A significant promotion of plant growth and yield increase was observed also in field conditions when lentil seeds were coated with Trichoderma strains and/or BAMs (Table 7). The plant dry weight vs. control increased by about 120 and 57\% when strains M10 or TH1, respectively, were used. Interestingly, the production of seed weight augmented up to $169 \%$ in TH1-treated plants compared with control (Table 7). Other treatments showing significant increases of seed weight/plant were those performed with strains M10 $(+112 \%$ vs. CTRL), T53 (+71\%), HK5 (+53\%), KV906 (+81\%), GV41 (+65), and with the metabolites $6 \mathrm{PP}(+36 \%)$ or HYTLO1 $(+147 \%)$. Regarding the mineral content, seed coating with strain KV906 or the BAM HYTLO1 determined the highest increases in both iron and zinc contents compared with water controls (Table 7). However, no significant differences in terms of promotion of plant growth, productivity or in terms of an increase in the mineral content were observed following the combined application of strain T22 and the metabolite HA when lentil plants were grown in field trials. 
Table 6. Effects of combined treatments with Trichoderma strains (T22, TH1, GV41) or metabolites (HA, 6PP, HYTLO1) on the lentil mineral content. Water treatments served as controls (CTRL). Treatments were applied to the seed (indicated on the left), then to the soil (indicated on the right). After $7 \mathrm{~d}$ from the soil treatment, another soil watering was carried out using the 1X FeZn solution (+FeZn) or water $(-\mathrm{FeZn})$. Data represent the mean value of three biological replicates \pm standard deviation (SD). Different letters in a column indicate statistically significant differences for $p<0.05$.

\begin{tabular}{|c|c|c|c|c|c|c|c|c|}
\hline \multirow{4}{*}{$\begin{array}{c}\text { Treatment Applied to Seed/Soil } \\
\text { CTRL }\end{array}$} & \multicolumn{8}{|c|}{ Mineral Content (mg/100 g Sample) } \\
\hline & \multicolumn{4}{|c|}{ IRON CONTENT } & \multicolumn{4}{|c|}{ ZINC CONTENT } \\
\hline & \multicolumn{2}{|c|}{$-\mathrm{FeZn}$} & \multicolumn{2}{|c|}{- FeZn } & \multicolumn{2}{|c|}{$-\mathrm{FeZn}$} & \multicolumn{2}{|c|}{$+\mathrm{FeZn}$} \\
\hline & 5.60 & $\pm 0.41 \mathrm{a}$ & 12.06 & $\pm 2.56 \mathrm{a}$ & 6.00 & $\pm 0.62 \mathrm{a}$ & 4.28 & $\pm 0.44 \mathrm{a}$ \\
\hline $\mathrm{HA} / \mathrm{H}_{2} \mathrm{O}$ & 7.76 & $\pm 0.18 \mathrm{bc}$ & 5.51 & $\pm 0.75 \mathrm{~b}$ & 5.69 & $\pm 0.41 \mathrm{ab}$ & 5.13 & $\pm 0.35 \mathrm{~b}$ \\
\hline HA/T22 & 6.31 & $\pm 0.56 \mathrm{a}$ & 12.46 & $\pm 1.69 \mathrm{a}$ & 5.23 & $\pm 0.63 \mathrm{ab}$ & 4.00 & $\pm 0.72 \mathrm{a}$ \\
\hline HA/TH1 & 6.26 & \pm 0.98 a & 13.21 & $\pm 1.45 \mathrm{a}$ & 5.28 & $\pm 0.66 \mathrm{ab}$ & 3.61 & $\pm 0.35 \mathrm{a}$ \\
\hline HA/GV41 & 6.29 & \pm 0.68 a & 46.74 & $\pm 6.51 \mathrm{c}$ & 4.39 & $\pm 0.58 \mathrm{~b}$ & 4.37 & $\pm 0.68 \mathrm{a}$ \\
\hline $6 \mathrm{PP} / \mathrm{H}_{2} \mathrm{O}$ & 9.13 & $\pm 0.85 \mathrm{c}$ & 8.57 & $\pm 0.96 \mathrm{~b}$ & 6.93 & $\pm 0.21 \mathrm{a}$ & 4.56 & $\pm 0.14 \mathrm{a}$ \\
\hline 6PP/T22 & 7.97 & $\pm 0.77 \mathrm{bc}$ & 13.29 & $\pm 1.69 \mathrm{a}$ & 5.36 & $\pm 0.81 \mathrm{ab}$ & 4.61 & $\pm 0.35 \mathrm{a}$ \\
\hline 6PP/TH1 & 3.91 & $\pm 0.45 \mathrm{~d}$ & 4.41 & $\pm 0.87 \mathrm{~b}$ & 5.08 & $\pm 0.80 \mathrm{ab}$ & 4.49 & $\pm 0.16 \mathrm{a}$ \\
\hline 6PP/GV41 & 7.77 & $\pm 0.85 \mathrm{bc}$ & 50.76 & $\pm 5.12 \mathrm{c}$ & 7.00 & $\pm 0.96 \mathrm{a}$ & 4.06 & $\pm 0.41 \mathrm{a}$ \\
\hline $\mathrm{HYTLO} 1 / \mathrm{H}_{2} \mathrm{O}$ & 7.02 & $\pm 1.00 \mathrm{ab}$ & 9.94 & $\pm 1.45 \mathrm{ab}$ & 6.61 & $\pm 0.36 \mathrm{a}$ & 4.56 & $\pm 0.14 \mathrm{a}$ \\
\hline HYTLO1/T22 & 5.49 & $\pm 0.66 \mathrm{a}$ & 7.22 & $\pm 0.98 \mathrm{~b}$ & 5.44 & $\pm 0.63 \mathrm{ab}$ & 3.94 & $\pm 0.34 \mathrm{a}$ \\
\hline HYTLO1/TH1 & 9.75 & $\pm 0.84 \mathrm{c}$ & 8.04 & $\pm 0.74 \mathrm{~b}$ & 5.61 & $\pm 0.31 \mathrm{a}$ & 4.79 & $\pm 0.23 \mathrm{a}$ \\
\hline HYTLO1/GV41 & 3.95 & $\pm 0.63 \mathrm{~d}$ & 7.61 & $\pm 0.84 \mathrm{~b}$ & 4.16 & $\pm 0.54 \mathrm{~b}$ & 5.10 & $\pm 0.23 \mathrm{~b}$ \\
\hline
\end{tabular}

Table 7. Effects of Trichoderma strains (TH1, M10, P1, T22, T53, HK5, CRN1, KV906 or GV41) or metabolites (HA, 6PP, HYTLO1), applied singly as seed coating, on the lentil mineral content. Plants were grown in field conditions and water treatments served as controls (CTRL). Data represent the mean value of three biological replicates (each one consisting of 10 plants) \pm standard error (SE). Different letters in a column indicate statistically significant differences for $p<0.05$. Significant increments compared with control (CTRL) are reported as \%; nd: Not determined.

\begin{tabular}{ccccccc}
\hline Treatment & $\begin{array}{c}\text { Plant Dry Weight } \\
\text { (g/Plant) }\end{array}$ & $\begin{array}{c}\text { Seed Weight } \\
\text { (g/Plant) }\end{array}$ & Mean \pm SE & \% & $\begin{array}{c}\text { Mineral Content } \\
\text { (ppm Solid) }\end{array}$ \\
& Mean \pm SE & Iron & Mean \pm SE (\%) & Mean \pm SE (\%) \\
\hline CTRL & $16.9 \pm 2.5 \mathrm{a}$ & - & $5.6 \pm 0.5 \mathrm{a}$ & - & $83.1 \pm 8.6 \mathrm{a}$ & $66.33 \pm 3.7 \mathrm{a}$ \\
TH1 & $26.6 \pm 2.7 \mathrm{~b}$ & +57 & $15.2 \pm 1.0 \mathrm{~b}$ & +169 & $82.2 \pm 6.6 \mathrm{a}$ & $62.43 \pm 1.8 \mathrm{a}$ \\
M10 & $37.1 \pm 0.4 \mathrm{c}$ & +120 & $12.0 \pm 0.4 \mathrm{c}$ & +112 & $85.3 \pm 10.8 \mathrm{a}$ & $66.38 \pm 5.5 \mathrm{a}$ \\
P1 & $\mathrm{nd}$ & - & $4.8 \pm 0.3 \mathrm{a}$ & - & $73.6 \pm 0.1 \mathrm{~b}$ & $59.94 \pm 1.0 \mathrm{~b}$ \\
T22 & $7.3 \pm 0.2 \mathrm{e}$ & - & $5.8 \pm 0.3 \mathrm{a}$ & - & $70.4 \pm 3.6 \mathrm{~b}$ & $56.40 \pm 82.9 \mathrm{~b}$ \\
T53 & $13.3 \pm 1.6 \mathrm{ad}$ & - & $9.7 \pm 0.5 \mathrm{~d}$ & +71 & $87.3 \pm 1.4 \mathrm{a}$ & $61.29 \pm 2.7 \mathrm{a}$ \\
HK5 & $16.5 \pm 1.4 \mathrm{a}$ & - & $8.7 \pm 2.4 \mathrm{de}$ & +53 & $83.5 \pm 2.0 \mathrm{a}$ & $68.82 \pm 1.1 \mathrm{a}$ \\
CRN1 & $17.5 \pm 1.6 \mathrm{a}$ & - & $5.3 \pm 2.1 \mathrm{a}$ & - & $82.1 \pm 20.5 \mathrm{a}$ & $66.44 \pm 7.6 \mathrm{a}$ \\
KV906 & $20.4 \pm 2.1 \mathrm{a}$ & - & $10.2 \pm 0.7 \mathrm{~cd}$ & +81 & $98.4 \pm 4.6 \mathrm{c}(+11 \%)$ & $73.97 \pm 6.7 \mathrm{c}(+18 \%)$ \\
GV41 & $17.9 \pm 4.5 \mathrm{a}$ & - & $9.3 \pm 1.9 \mathrm{cde}$ & +65 & $76.1 \pm 1.7 \mathrm{~b}$ & $62.28 \pm 4.2 \mathrm{a}$ \\
HA & $8.6 \pm 0.6 \mathrm{e}$ & - & $5.1 \pm 0.7 \mathrm{a}$ & - & $90.6 \pm 0.1 \mathrm{a}$ & $66.72 \pm 4.2 \mathrm{a}$ \\
6PP & $12.9 \pm 0.7 \mathrm{~d}$ & - & $7.6 \pm 0.4 \mathrm{de}$ & +36 & $73.6 \pm 0.9 \mathrm{~b}$ & $62.12 \pm 0.1 \mathrm{a}$ \\
HYTLO1 & $21.5 \pm 3.4 \mathrm{ab}$ & - & $14.0 \pm 2.9 \mathrm{~b}$ & +147 & $99.9 \pm 2.0 \mathrm{c}(+6 \%)$ & $70.55 \pm 2.2 \mathrm{c}(+20 \%)$ \\
T22 + HA & $16.3 \pm 2.2 \mathrm{ad}$ & - & $6.6 \pm 1.3 \mathrm{ae}$ & - & $88.6 \pm 5.0 \mathrm{a}$ & $67.45 \pm 3.3 \mathrm{a}$ \\
\hline
\end{tabular}




\section{Discussion}

Lentils are cultivated worldwide, especially in non-optimal, temperate agricultural zones. The major global producers in 2019 were Canada and India, accounting for 37 and $21 \%$, respectively, of the global production [30]. Lentils are an excellent source of micronutrients, particularly iron $(\mathrm{Fe})$ and zinc $(\mathrm{Zn})$. In addition, they are low in fat, contain a high amount of protein (average $23 \%$ ), and are rich in some essential amino acids (such as lysine and phenylalanine) [31]. The biofortification of crops with microorganisms represents an innovative strategy to increase the nutritional content of crops, thus contributing to contrast the malnutrition $[23,32,33]$. In this work, the use of a microbial technology, based on antagonistic fungi of the genus Trichoderma and/or their metabolic products has been proposed in order to increase the nutritional value of an important legume, such as lentil. Trichoderma spp. are widely used in agriculture as biocontrol agents and are well known for their ability to establish complex interactions with plants, promoting their growth, inducing systemic resistance, and increasing the tolerance to abiotic stresses [15,16,34]. Recently, Bazghaleh et al. showed that the lentil genotype greatly influenced the colonization of root-associated fungi, including Trichoderma beneficial species, and affected the biocontrol against the oomycete Aphanomyces euteiches [35].

We tested several species and strains of Trichoderma, which include isolates that are able to exert beneficial effects on plants. Eleven strains, identified by morphological characters and molecular techniques, have been used in this study. Moreover, the experimental design included three BAMs (6PP, HA, and HYTLO1) produced by Trichoderma strains, previously isolated and characterized and known for their ability to control pathogens and establish beneficial interactions with plants [25-28]. Among these metabolites, HA showed the ability to chelate iron [27]. The iron sequestration can regulate the competition for nutrients that develop between soil microorganisms [36] and may represent one of the mechanisms of active biocontrol against plant pathogens $[15,37,38]$.

Here, in greenhouse and field assays, we have performed an evaluation of the effects of strains or metabolites of Trichoderma on the growth and mineral content of lentil plants of the Canadian variety CDC MAXIM CL. The analyses focused mainly on iron and zinc, since these minerals are among the micronutrients that are most frequently deficient in human nutrition, but present in legume pulses $[23,39,40]$. The seed treatment with Trichoderma strains or metabolites affected the germination of lentil seeds, according to the strain/compound used in greenhouse experiments (Figure 4). Up to an approximately $70 \%$ increase in seed germination was found in TH1- and T22-treated samples compared with the untreated control. In addition, significant improvements were obtained with the BAMs HA and HYTLO1. When seed coating was followed by soil washing with Trichoderma spore suspensions/BAMs solutions and mineral fertilization, plants showed a better appearance compared with water-controls, in terms of development, physiology, and productivity (Figures 1 and 3). In field conditions, the highest improvements of plant dry weight and seed weight were observed following seed coating with M10 and TH1 T. harzianum spores (Table 7). Similar biostimulant activities exerted by Trichoderma species and their metabolites have been well documented on different crops $[17,19,20,41-43]$, including legumes [21,34,44,45]. Experimental evidence indicated that the use of plant growth-promoting microbes and their bioactive compounds may represent a valid strategy to withstand biotic and abiotic stresses that could affect plant yield and performance [17,46-49].

In our study, the mineral content of lentil plants was affected differently by the seed/soil treatment with Trichoderma spores/BAMs, as well as by the mode and number of applications. Significant $(p<0.05)$ increases in Fe were observed in plants treated with strains T22, TH1, and GV41 (Table 4) or with the compounds HA and 6PP (Figure 2). Similarly, the content of $\mathrm{Zn}$ was affected by Trichoderma applications (Table 4). Some studies showed that several species of Trichoderma (particularly T. asperellum) can increase the concentration of iron and other minerals in wheat and lupine plants [11,12]. Previously, Altomare et al. have demonstrated the ability of T22 strain of T. harzianum to solubilize 
poorly soluble phosphates and mineral compounds (including $\mathrm{Fe}_{2} \mathrm{O}_{3}, \mathrm{MnO}_{2}, \mathrm{Zn}$ ) through chelation and reduction mechanisms, which are also involved in biocontrol processes against plant pathogens and, probably, in promoting the plant growth [50].

Furthermore, we tested if combinations of the living microbe and bioactive molecules in repeated applications (to the seed and then to the soil) could exert a better effect than each component applied singly. Our data indicated that under greenhouse conditions a combined application of spores and BAMs or each component applied singly increased iron content (Tables 5 and 6). Overall, single treatments consisting of soil watering with Trichoderma strains or BAMs determined the higher increase in Fe content compared with seed coating, both in the presence or absence of mineral fertilization ( $\pm 1 \mathrm{X}$ FeZn solution). However, the highest Fe contents were found in plants treated with the combination of HA or 6PP applied to the seeds and the strain GV41 watered to the soil (Table 6). In addition, the field experiment revealed a significant increase in Fe and $\mathrm{Zn}$ contents in lentil plants treated with strain KV906 or the hydrophobin HYTLO1, both used as seed treatments (Table 7). This finding underlines the importance of correct formulation and timing for the application of bioformulates consisting of living microbes and/or natural compounds.

The results obtained in this work indicate that the application of selected strains of Trichoderma to lentil plant may improve the nutritional value of these food crops, i.e., by increasing the contents of important mineral micronutrients, such as iron and zinc. In a previous study, we demonstrated that the application of selected Trichoderma strains and metabolites enhanced the productivity of soybean and improved the lipid content in this oilseed crop [21]. Similarly, Yadav et al. investigated the effects of microbial applications based on Pseudomonas and Trichoderma inocula on the growth and nutritional value of chickpea [51]. A fusant strain of Trichoderma showed the ability to increase amino acids and the mineral content of chickpea [44]. However, the effects on plant growth and productivity, as well as on mineral content, varied not only according to the strain/compound used, but also to the mode of application (seed/soil treatments) and plant growth conditions (greenhouse/field). This finding underlines the importance in defining opportune selection processes to optimize the outcomes resulting from biofortification or plant growth promotion strategies.

The use of BAMs produced by these fungi can represent a valid alternative to the use of the living microorganism, offering a comparable effectiveness and, in some cases, superior to the producer strain. The production of siderophores by T. asperellum, for example, reduced the effects of salt stress in cucumber plants thanks to the ability of these extracts to chelate or solubilize the iron by reducing $\mathrm{Fe}^{3+}$ to $\mathrm{Fe}^{2+}$ [52].

The proposed microbial biotechnology could broaden the concept of traditional agronomic biofortification, usually consisting of the administration of fertilizers containing essential mineral micronutrients. This strategy intends to promote the use of organisms and/or natural substances to obtain numerous benefits, ranging from pest control to the promotion of plant growth, induction of resistance to improve the quality of crops, with obvious positive implications on human and animal nutrition. To this, the economic benefits and the opportunity to build a new biotechnology can be added. This increases the nutritional value of the crop with deployment times that are below those required for the application of genetically improved crops [53].

\section{Conclusions}

The agronomic biofortification using beneficial microbes or their metabolites intends to contribute to the prevention of MNM. Our results confirmed that Trichoderma strains and their BAMs affect the growth, productivity, and mineral content of lentil plants. Here, the highest increase in plant growth and productivity was obtained using Trichoderma strain TH1, both in greenhouse and field conditions. In addition, combined applications of BAMs to the seeds and strains (in particular, T22, TH1 or GV41) to the soil determined the higher increases in mineral content compared with the control, regardless of additional fertilization. However, the type and mode of application, as well as the plant growth 
conditions determined differences in treated plants. Our findings underline the importance of properly selecting the best strain/compound and its formulation to achieve the highest performance, according to the desired task. Additional extensive studies are needed to evaluate whether the increase in the minerals obtained with the use of bioformulates corresponds to a greater bioavailability of micronutrients for the final consumer of the food. Similarly, it is necessary to clarify whether the effects observed in this study can be played on other varieties of lentils or other legumes.

Supplementary Materials: The following are available online at https:/ /www.mdpi.com/article/10 $.3390 /$ microorganisms10010087/s1. Figure S1: Calibration curves of iron (Fe) and zinc (Zn) obtained by atomic absorption spectroscopy using commercial standard solutions; Table S1: Treatments performed in experiment \#A with Trichoderma strains (T22, M10, P1) or metabolites (HA, 6PP); Table S2: Treatments performed in experiment \#C with Trichoderma strains (T22, TH1, GV41) or metabolites (HA, 6PP, HYTLO1).

Author Contributions: Conceptualization, R.M., A.V. and S.W.; methodology, R.M. and S.W.; experimental design, R.M., N.L., A.P., A.V. and S.W.; data collection and processing, R.M., N.L., N.B. and P.P.; writing - original draft preparation, R.M., N.L. and S.W.; writing-review and editing, R.M., A.P., A.V. and S.W. All authors have read and agreed to the published version of the manuscript.

Funding: This research was funded by the NSERC Industrial Research Chair program and Saskatchewan Pulse Growers; PRIN 2017 (grant number PROSPECT 2017JLN833); MISE Sportello Agrifood DM 5/3/2018 (grant VIABIO).

Institutional Review Board Statement: Not applicable.

Informed Consent Statement: Not applicable.

Data Availability Statement: Not applicable.

Acknowledgments: The authors N.B., P.P. and A.V. thank Saskatchewan Pulse Growers for providing the lentil seeds used for the experiments. The authors R.M., N.L., A.P. and S.W. thank Rosaria Varlese, Salvatore Spano, Augusto Verdino, Antonio De Martino, and Francesco Scognamiglio from University of Naples Federico II for the technical assistance during the experiments and data collection.

Conflicts of Interest: The authors declare no conflict of interest.

\section{References}

1. Food and Agriculture Organization (FAO) of the United Nations. The Future of Food and Agriculture. Trends and Challenges; FAO: Rome, Italy, 2017; p. 5.

2. Strobbe, S.; Van Der Straeten, D. Toward Eradication of B-Vitamin Deficiencies: Considerations for Crop Biofortification. Front. Plant Sci. 2018, 9, 443. [CrossRef]

3. Bailey, R.L.; West, K.P.; Black, R.E. The epidemiology of global micronutrient deficiencies. Ann. Nutr. Metab. 2015, 66, 22-33. [CrossRef]

4. Darnton-Hill, I.; Webb, P.; Harvey, P.W.; Hunt, J.M.; Dalmiya, N.; Chopra, M.; Ball, M.J.; Bloem, M.W.; de Benoist, B. Micronutrient deficiencies and gender: Social and economic costs. Am. J. Clin. Nutr. 2005, 81, 1198S-1205S. [CrossRef]

5. Ruel-Bergeron, J.C.; Stevens, G.A.; Sugimoto, J.D.; Roos, F.F.; Ezzati, M.; Black, R.E.; Kraemer, K. Global update and trends of hidden hunger, 1995-2011: The hidden hunger index. PLoS ONE 2015, 10, e0143497. [CrossRef]

6. Copenhagen Consensus. Solutions to Global Challenges. 2012. Available online: http://www.copenhagenconsensus.com/ copenhagen-consensus-iii/ outcome (accessed on 30 November 2021).

7. Bouis, H.E.; Saltzman, A. Improving nutrition through biofortification: A review of evidence from HarvestPlus, 2003 through 2016. Glob. Food Secur. 2017, 12, 49-58. [CrossRef]

8. Gangashetty, P.I.; Riyazaddin, M.; Sanogo, M.D.; Inousa, D.; Issoufou, K.A.; Asungre, P.A.; Sy, O.; Govindaraj, M.; Ignatius, A.I Identification of High-Yielding Iron-Biofortified Open-Pollinated Varieties of Pearl Millet in West Africa. Front. Plant Sci. 2021, 12, 688937. [CrossRef]

9. Reinbott, A.; Schelling, A.; Kuchenbecker, J.; Jeremias, T.; Russell, I.; Kevanna, O.; Krawinkel, M.B.; Jordan, I. Nutrition education linked to agricultural interventions improved child dietary diversity in rural Cambodia. Br. J. Nutr. 2016, 116, 1457-1468. [CrossRef]

10. Pfeiffer, W.H.; McClafferty, B. HarvestPlus: Breeding Crops for Better Nutrition. Crop Sci. 2007, 47, S88-S105. [CrossRef]

11. de Santiago, A.; Quintero, J.M.; Avilés, M.; Delgado, A. Effect of Trichoderma asperellum strain T34 on iron nutrition in white lupin. Soil Biol. Biochem. 2009, 41, 2453-2459. [CrossRef] 
12. de Santiago, A.; Quintero, J.M.; Avilés, M.; Delgado, A. Effect of Trichoderma asperellum strain T34 on iron, copper, manganese, and zinc uptake by wheat grown on a calcareous medium. Plant Soil 2011, 342, 97-104. [CrossRef]

13. Poveda, J.; Eugui, D.; Abril-Urías, P.; Velasco, P. Endophytic fungi as direct plant growth promoters for sustainable agricultural production. Symbiosis 2021, 85, 1-19. [CrossRef]

14. Rigobelo, E.C.; Baron, N.C. Endophytic fungi: A tool for plant growth promotion and sustainable agriculture. Mycology 2021. [CrossRef]

15. Alfiky, A.; Weisskopf, L. Deciphering Trichoderma-Plant-Pathogen Interactions for Better Development of Biocontrol Applications J. Fungi 2021, 7, 61. [CrossRef]

16. Woo, S.L.; Ruocco, M.; Vinale, F.; Nigro, M.; Marra, R.; Lombardi, N.; Pascale, A.; Lanzuise, S.; Manganiello, G.; Lorito, M. Trichoderma-based products and their widespread use in agriculture. Open Mycol. J. 2014, 8, 71-126. [CrossRef]

17. Oljira, A.M.; Hussain, T.; Waghmode, T.R.; Zhao, H.; Sun, H.; Liu, X.; Wang, X.; Liu, B. Trichoderma enhances net photosynthesis, water use efficiency, and growth of wheat (Triticum aestivum L.) under salt stress. Microorganisms 2020, 8, 1565. [CrossRef]

18. Gupta, R.; Bar, M. Plant immunity, priming, and systemic resistance as mechanisms for Trichoderma spp. biocontrol. In Trichoderma; Springer: Singapore, 2020; pp. 81-110.

19. Sánchez-Montesinos, B.; Diánez, F.; Moreno-Gavíra, A.; Gea, F.J.; Santos, M. Role of Trichoderma aggressivum f. europaeum as Plant-Growth Promoter in Horticulture. Agronomy 2020, 10, 1004. [CrossRef]

20. Velasco, P.; Rodríguez, V.M.; Soengas, P.; Poveda, J. Trichoderma hamatum Increases Productivity, Glucosinolate Content and Antioxidant Potential of Different Leafy Brassica Vegetables. Plants 2021, 10, 2449. [CrossRef]

21. Marra, R.; Lombardi, N.; d'Errico, G.; Troisi, J.; Scala, G.; Vinale, F.; Woo, S.L.; Bonanomi, G.; Lorito, M. Application of Trichoderma strains and metabolites enhances soybean productivity and nutrient content. J. Agric. Food Chem. 2019, 67, 1814-1822. [CrossRef]

22. Khan, R.A.A.; Najeeb, S.; Hussain, S.; Xie, B.; Li, Y. Bioactive Secondary Metabolites from Trichoderma spp. against Phytopathogenic Fungi. Microorganisms 2020, 8, 817. [CrossRef]

23. Rehman, H.M.; Cooper, J.W.; Lam, H.-M.; Yang, S.H. Legume biofortification is an underexploited strategy for combatting hidden hunger. Plant Cell Environ. 2018, 42, 52-70. [CrossRef]

24. Characteristics of Lentil (Lens culinaris L.) Variety CDC MAXIM CL. Available online: https:/ / agriculture.basf.ca/west/products/ seeds-and-systems / clearfield / clearfield-lentils / varieties.html (accessed on 15 October 2021).

25. Vinale, F.; Sivasithamparam, K.; Ghisalberti, E.L.; Marra, R.; Barbetti, M.J.; Li, H.; Woo, S.L.; Lorito, M. A novel role for Trichoderma secondary metabolites in the interactions with plants. Physiol. Mol. Plant Pathol. 2008, 72, 80-86. [CrossRef]

26. Vinale, F.; Flematti, G.; Sivasithamparam, K.; Lorito, M.; Marra, R.; Skelton, B.W.; Ghisalberti, E.L. Harzianic Acid, an Antifungal and Plant Growth Promoting Metabolite from Trichoderma harzianum. J. Nat. Prod. 2009, 72, 2032-2035. [CrossRef]

27. Vinale, F.; Nigro, M.; Sivasithamparam, K.; Flematti, G.; Ghisalberti, E.L.; Ruocco, M.; Varlese, R.; Marra, R.; Lanzuise, S.; Eid, A.; et al. Harzianic acid: A novel siderophore from Trichoderma harzianum. FEMS Microbiol. Lett. 2013, 347, 123-129. [CrossRef]

28. Ruocco, M.; Lanzuise, S.; Lombardi, N.; Woo, S.L.; Vinale, F.; Marra, R.L.; Varlese, R.; Manganiello, G.; Pascale, A.; Scala, V.; et al. Multiple Roles and Effects of a Novel Trichoderma Hydrophobin. Mol. Plant Microbe Interact. 2015, 28, 167-179. [CrossRef]

29. Gericke, S.; Kurmies, B. Colorimetrische Bestimmung der Phosphorsäure mit Vanadat-Molybdat. Z. Anal. Chem. 1952, 137, 15-22. [CrossRef]

30. FAOSTAT. 2021. Available online: https:/ / www.fao.org/faostat/en/\#data (accessed on 30 November 2021).

31. US Department of Agriculture. National Nutrient Database for Standard Reference Release 28 (2016). "Full Report (All Nutrients): 16069, Lentils, Raw". Retrieved 15 December 2015; US Department of Agriculture: Washington, DC, USA, 2016.

32. Ye, Y.; Qu, J.; Pu, Y.; Rao, S.; Xu, F.; Wu, C. Selenium Biofortification of Crop Food by Beneficial Microorganisms. J. Fungi 2020, 6, 59. [CrossRef]

33. Shahzad, R.; Jamil, S.; Ahmad, S.; Nisar, A.; Khan, S.; Amina, Z.; Kanwal, S.; Aslam, H.M.U.; Gill, R.A.; Zhou, W. Biofortification of Cereals and Pulses Using New Breeding Techniques: Current and Future Perspectives. Front. Nutr. 2021, 8, 721728. [CrossRef]

34. Mukherjee, M.; Mukherjee, P.K.; Horwitz, B.A.; Zachow, C.; Berg, G.; Zeilinger, S. Trichoderma-Plant-Pathogen Interactions: Advances in Genetics of Biological Control. Indian J. Microbiol. 2012, 52, 522-529. [CrossRef]

35. Bazghaleh, N.; Prashar, P.; Woo, S.; Vandenberg, A. Effects of Lentil Genotype on the Colonization of Beneficial Trichoderma Species and Biocontrol of Aphanomyces Root Rot. Microorganisms 2020, 8, 1290. [CrossRef]

36. Winkelmann, G. Ecology of siderophores with special reference to the fungi. Biometals 2007, 20, 379-392. [CrossRef]

37. Lemanceau, P.; Bauer, P.; Kraemer, S.; Briat, J.F. Iron dynamics in the rizosphere as a case study for analyzing interactions between soils, plants and microbes. Plant Soil 2009, 321, 513-535. [CrossRef]

38. Marschner, P.; Crowley, D.; Rengel, Z. Rhizosphere interactions between microorganisms and plants govern iron and phosphorus acquisition along the root axis-model and research methods. Soil Biol. Biochem. 2011, 43, 883-894. [CrossRef]

39. Palmgren, M.G.; Clemens, S.; Williams, L.E.; Krämer, U.; Borg, S.; Schjørring, J.K.; Sanders, D. Zinc biofortification of cereals: Problems and solutions. Trends Plant Sci. 2008, 13, 464-473. [CrossRef]

40. Curie, C.; Briat, J.F. Iron transport and signaling in plants. Annu. Rev. Plant Biol. 2003, 54, 183-206. [CrossRef]

41. Lombardi, N.; Caira, S.; Troise, A.D.; Scaloni, A.; Vitaglione, P.; Vinale, F.; Marra, R.; Salzano, A.M.; Lorito, M.; Woo, S.L. Trichoderma applications on strawberry plants modulate the physiological processes positively affecting fruit production and quality. Front. Microbiol. 2020, 11, 1364. [CrossRef] 
42. Lombardi, N.; Salzano, A.M.; Troise, A.D.; Scaloni, A.; Vitaglione, P.; Vinale, F.; Marra, R.; Caira, S.; Lorito, M.; d’Errico, G.; et al. Effect of Trichoderma Bioactive Metabolite Treatments on the Production, Quality, and Protein Profile of Strawberry Fruits. J. Agric. Food Chem. 2020, 68, 7246-7258. [CrossRef]

43. Woo, S.L.; Pepe, O. Microbial Consortia: Promising Probiotics as Plant Biostimulants for Sustainable Agriculture. Front. Plant Sci. 2018, 9, 1801. [CrossRef]

44. Mishra, A.; Nautiyal, C.S. A novel Trichoderma fusant for enhancing nutritional value and defence activity in chickpea. Physiol. Mol. Biol. Plants 2018, 24, 411-422. [CrossRef]

45. Poveda, J. Biological control of Fusarium oxysporum f. sp. ciceri and Ascochyta rabiei infecting protected geographical indication Fuentesaúco-Chickpea by Trichoderma species. Eur. J. Plant Pathol. 2021, 160, 825-840. [CrossRef]

46. Silletti, S.; Di Stasio, E.; Van Oosten, M.J.; Ventorino, V.; Pepe, O.; Napolitano, M.; Marra, R.; Woo, S.L.; Cirillo, V.; Maggio, A. Biostimulant Activity of Azotobacter chroococcum and Trichoderma harzianum in Durum Wheat under Water and Nitrogen Deficiency. Agronomy 2021, 11, 380. [CrossRef]

47. Mastouri, F.; Björkman, T.; Harman, G.E. Seed treatment with Trichoderma harzianum alleviates biotic, abiotic and physiological stresses in germinating seeds and seedlings. Phytopathology 2010, 100, 1213-1221. [CrossRef]

48. Fiorentino, N.; Ventorino, V.; Woo, S.L.; Pepe, O.M.; De Rosa, A.; Gioia, L.; Romano, I.; Lombardi, N.; Napolitano, M.; Colla, G.; et al. Trichoderma-Based Biostimulants Modulate Rhizosphere Microbial Populations and Improve N Uptake Efficiency, Yield, and Nutritional Quality of Leafy Vegetables. Front. Plant Sci. 2018, 9, 743. [CrossRef]

49. Guzmán-Guzmán, P.; Porras-Troncoso, M.D.; Olmedo-Monfil, V.; Herrera-Estrella, A. Trichoderma Species: Versatile Plant Symbionts. Phytopathology 2019, 109, 6-16. [CrossRef]

50. Altomare, C.; Norvell, W.A.; Björkman, T.; Harman, G.E. Solubilization of phosphates and micronutrients by the Plant-GrowthPromoting and biocontrol fungus Trichoderma harzianum Rifai 1295-22. Appl. Environ. Microbiol. 1999, 65, 2926-2933. [CrossRef]

51. Yadav, S.K.; Singh, S.; Singh, H.B.; Sarma, B.K. Compatible rhizosphere-competent microbial consortium adds value to the nutritional quality in edible parts of chickpea. J. Agric. Food Chem. 2017, 65, 6122-6130. [CrossRef]

52. Zhao, L.; Wang, F.; Zhang, Y.; Zhang, J. Involvement of Trichoderma asperellum strain T6 in regulating iron acquisition in plants. J. Basic Microbiol. 2014, 54, S115-S124. [CrossRef]

53. Carvalho, S.M.P.; Vasconcelos, M.W. Producing more with less: Strategies and novel technologies for plant-based food biofortification. Food Res. Int. 2013, 54, 961-971. [CrossRef] 